\title{
ANALISIS PUTUSAN PEMBATALAN PERJANJIAN PERDAMAIAN HOMOLOGASI PADA KASUS KEPAILITAN PT NJONJA MENEER \\ (STUDI KASUS: PUTUSAN PENGADILAN NIAGA SEMARANG NOMOR 11/PDT.SUS-PAILIT/2017/PN NIAGA SMG. JO. PUTUSAN MAHKAMAH AGUNG NOMOR 1397 K/PDT.SUS-PAILIT/2017).
}

\author{
Indah Jacinda \\ (Mahasiswa Program S1 Fakultas Hukum Universitas Tarumanagara) \\ (ijacinda19@gmail.com) \\ Dr. S. Atalim, S.H., M.H. \\ (Corresponding Author) \\ (Dosen Fakultas Hukum Universitas Tarumanagara. Meraih Sarjana Hukum pada Fakultas Hukum \\ Universitas Indonesia, Magister Hukum pada Fakultas Hukum Universitas Indonesia, Doktor (Dr.) \\ pada Fakultas Hukum Universitas Parahyangan) \\ (st_atalim@yahoo.com)
}

\begin{abstract}
A form of reconciliation in Suspension of Payment is an agreed composition plan, and the composition plan must get the court's ratification (homologation). According to Article 170 of the Bankruptcy Law number 37/2004, the creditor can request the cancellation of the composition plan that has been approved if the debtor fails (negligent) to fulfill their obligations. Furthermore, in Article 291 Paragraph 2 of the Bankruptcy Law states that if the cancellation is approved, the debtor must be declared bankrupt. And in this case, PT Njonja Meneer was declared bankrupt because they were considered negligent in fulfilling their obligation according to the composition plan, which if we look in Indonesian Civil Code, on Article 1238 it's stated that someone can only be said to be negligent if they do not carry out their obligations after the due date and have received a notice beforehand. And in this case, the composition plan's due year is still in 2020 but in 2017, the debtor has already called negligent and declared bankrupt by the court. Therefore, while the research methods in this journal use normative research methods supported by interview data, this journal will examine further about the composition plan itself and the term of negligent in fulfilling the obligations according to the bankruptcy law.
\end{abstract}

Keywords: Composition Plan, Suspension Of Payment, Negligent, PT Njonja Meneer, Bankruptcy Law. 
Analisis Putusan Pembatalan Perjanjian Perdamaian Homologasi Pada Kasus Kepailitan PT Njonja Meneer (Studi Kasus: Putusan Pengadilan Niaga Semarang Nomor 11/Pdt.Sus-Pailit/2017/Pn Niaga Smg. Jo. Putusan Mahkamah Agung Nomor 1397 K/Pdt.Sus-Pailit/2017)

\section{PENDAHULUAN}

\section{A. Latar Belakang}

Perusahaan dalam bentuk badan hukum maupun bukan badan hukum memiliki tujuan untuk melakukan kegiatan usaha untuk memperoleh keuntungan dengan menjalankan usahanya secara tetap dan terus menerus. ${ }^{1)}$ Perusahaan dapat mengembangkan kegiatan usahanya apabila didukung dengan modal yang cukup. Modal dapat diperoleh dengan memakai modal maupun melakukan pinjaman dari pihak lain sebagai cara untuk menolong perusahaannya meningkatkan usahanya dan keuntungan yang didapatkan baik dari sisi waktu maupun dari sisi jumlah. ${ }^{2)}$

Kegiatan peminjaman modal merupakan bentuk dari perjanjian utang piutang atau perjanjian pinjam meminjam yang melibatkan antara peminjam (debitur) dan yang meminjamkan (kreditur). Perjanjian tersebut akan berisi mengenai peristiwa dimana seseorang berjanji dengan seseorang maupun dua orang lain untuk mekajsanakan pinjam meminjam tersebut. ${ }^{3)}$ Dari perjanjian tersebut maka sangat memungkinkan lahirnya wanprestasi atau yang dapat diartikan sebagai pengingkaran yang dilakukan salah satu pihak dari kesepakatan yang telah dibuat. Pastinya baik hal itu dalam bentuk perjanjian sepihak (cumacuma) maupun timbal balik (atas beban) akan merugikan pihak kreditur.

Apabila debitur tidak mampu membayar atau ketidakmampuan membayar debitur (insolvensi) hutang-hutangnya kepada pihak kreditur ini dapat menyebabkan suatu perusahaan di kenakan Penundaan Kewajiban Pembayaran Utang ("PKPU"). Adapun yang menjadi maksud dan tujuan PKPU adalah sesuai dengan yang tercantum pada ketentuan Pasal 222 Ayat (2) dan (3) Undang-

\footnotetext{
1) Dijan Widijowati, Hukum Dagang, (Yogyakarta: Andi Offset, 2012), hal. 15.

2) Elsi Kartika Sari dan Advendi Simangunsong, Hukum Dalam Ekonomi, (Jakarta: Grasindo, 2007), hal. 34.

3) Wirjono Prodjodikoro, Azas-Azas Hukum Perjanjian, (Bandung: Mandar Maju, 2000), hal. 4.
} 
Undang Nomor. 37 Tahun 2004 tentang Kepailitan dan Penundaan Kewajiban Pembayaran Utang (“UUK PKPKU”), terkandung makna bahwa, sesungguhnya tujuan dari PKPU itu sendiri adalah melakukan perdamaian yang berupa tawaran rencana pembayaran seluruh atau sebagian hutang-hutang debitur kepada kreditur. Yang berarti dalam proses PKPU tersebut sangat mungkin dilakukan perdamaian.

Yang dimaksud perdamaian dalam PKPU diatur dalam Bab III, Bagian Kedua, Pasal 265 sampai dengan Pasal 294 UUK PKPU. Pasal 265 UUK PKPU menjelaskan bahwa rencana perdamaian berhak diajukan debitur kepada kreditur-krediturnya bahkan setelah debitur mengajukan PKPU sekalipun. Berdasarkan mekanisme PKPU yang ditentukan oleh UUK PKPU berarti bahwa yang berhak merundingkan dan menyepakati rencana perdamaian adalah debitur dan kreditur itu sendiri dan tidak boleh adanya intervensi dari pihak-pihak lain dalam perundingan dan penyepakatannya.

Namun, rencana perdamaian yang diterima tidak dapat langsung dilaksanakan dikarenakan masih ada tahapan lain yang perlu ditempuh yaitu memperoleh pengesahan (homologasi) terhadap perdamaian tersebut dari Pengadilan Niaga yang berwenang. Dalam perdamaian tersebut debitur diwajibkan untuk menyelesaikan hutang-hutangnya, dan diharapkan kepada para kreditur untuk melepaskan segala tuntutannya, serta memusyawarahkan masingmasing kepentingan yang diinginkan agar tercapainya suatu kesepakatan. Rencana perdamaian ini memiliki konsekuensi yaitu apabila telah disepakati antara debitur dan kreditur-krediturnya, setelah itu ditemukan adanya cidera janji yang dilakukan oleh debitur, maka otomatis akan mengakibatkan debitur dijatuhkan pailit oleh pengadilan. ${ }^{4)}$

Menurut Pasal 170 Ayat 1 Undang-Undang Nomor 37 Tahun 2004 tentang

4) Sutan Remy Sjahdeini, Hukum Kepailitan Memahami Undang-Undang No.37 Tahun 2004 Tentang Kepailitan, (Jakarta: Pustaka Utama Grafiti, 2009), hal. 396. 
Kepailitan dan Penundaan Kewajiban Pembayaran Utang tercantum "Pembatalam suatu perdamaian dapat diajukan oleh kreditur apabila debitur lalai dalam pemenuhan isi perdamaian tersebut".

Selanjutnya, Pasal 291 Ayat 2 Undang-Undang Nomor 37 Tahun 2004 tentang Kepailitan dan Penundaan Kewajiban Pembayaran Utang tercantum bahwa "Dalam putusan Pengadilan yang membatalkan perdamaian, Debitur juga harus dinyatakan pailit.".

Mengingat hal tersebut, Penulis tertarik untuk menguraikan lebih lanjut mengenai salah satu perkara yang telah diputus oleh Pengadilan Niaga Semarang dalam putusan Nomor: 11/Pdt.Sus-PKPU/2017/PN Niaga Smg jo. Nomor: 01/Pdt.Sus-PKPU/2015/PN Niaga Smg. Dimana PT Njonja Meneer dituntut oleh Hendrianto Bambang Santoso untuk dibatalkan perjanjian perdamaian homologasinya sehingga menyebabkan PT Njonja Meneer harus dipailitkan. Begitu pula putusan Mahkamah Agung Nomor: 1397 K/Pdt.Sus-Pailit/2017 yang menolak permohonan kasasi PT Njonja Meneer dan menyetujui pembatalan perjanjian perdamaian homoloagasi tersebut sehingga menyebabkan pailitnya PT Njonja Meneer.

Hendra Bambang Santoso salah satu kreditur PT Njonja Meneer menganggap PT Njonja Meneer lalai atau wanprestasi dalam pemenuhan prestasi perjanjian perdamaian homoloagasi tersebut. Padahal menurut M. Yahya Harahap, menurut hukum seorang debitur tidak dapat dikatakan lalai atau alpa dalam memenuhi kewajibannya apabila belum menerima pemberitahuan secara tertulis yang dibuat oleh kreditur, meskipun telah ditentukan secara tegas kapan pemenuhan perjanjiannya dalam perjanjiannya. ${ }^{5)}$

Menurut Pasal 1238 KUH Perdata tercantum bahwa "Si berutang adalah lalai, apabila ia dengan surat perintah atau dengan sebuah akta sejenis itu telah dinyatakan lalai, atau demi perikatan sendiri, ialah jika ini menetapkan bahwa si

\footnotetext{
5) M Yahya Harahap, Hukum Acara Perdata, (Jakarta : Sinar Grafika, 2005), hal. 454.
} 
berutang harus dianggap lalai dengan lewatnya waktu yang ditentukan". Dari ketentuan Pasal tersebut dapat dikatakan bahwa debitur dinyatakan wanprestasi apabila debitur memiliki utang atau tagihan yang telah jatuh tempo atau sudah menerima surat peringatan atau somasi. Dan pada kasus ini PT Njonja Meneer tidak menerima somasi sama sekali.

Kemudian dalam kasus tersebut, menurut PT Njonja Meneer, Pemohon (kreditur) mengajukan permohonan terlalu dini dalam menganggap debitur lalai, karena perjanjian perdamaian tersebut dimulai dari Juli 2015 dan berakhir pada Juni 2020. Menurut bukti T-5 sampai dengan T-18, PT Njonja Meneer selalu melakukan pembayaran setiap bulannya dengan total Rp 412.094.000,00 (empat ratus dua belas juta sembilan puluh empat ribu rupiah) dari jumlah seluruh utang Rp 7.040.970.500,00 (tujuh miliar empat puluh juta sembilan ratus tujuh puluh ribu lima ratus rupiah).

Kasus ini berakhir dengan keputusan pada tingkat kasasi di mahkamah agung yang diawali keputusan pengadilan niaga semarang dimana dalam putusannya menyatakan bahwa perjanjian perdamaian homologasi tersebut cukup beralasan untuk dibatalkan karena jumlah pembayaran yang dilakukan PT Njonja Meneer tersebut tidak sebanding (tidak signifikan) dengan kewajiban pembayarannya, maka PT Njonja Meneer disebut lalai dalam memenuhi kewajiban pembayaran dan lebih jauh lagi, menurut hakim pengadilan niaga semarang keadaan tersebut cukup untuk membuktikan PT Njonja Meneer lalai memenuhi kewajibannya tanpa perlu menunggu batas waktu pembayaran berakhir.

Hal ini berlaku sama pada tingkat kasasi di Mahkamah Agung, dalam putusannya, hakim menyatakan bahwa pengadilan negeri semarang tidak salah menerapkan hukum dengan pertimbangan bahwa PT Njonja Meneer telah melakukan wanprestasi, sehingga terbukti lalai tidak memenuhi isi perjanjian perdamaian tersebut. 
Setelah menguraikan latar belakang tersebut, Penulis merasa tertarik untuk mengkaji mengenai topik tersebut secara komperhensif dan menuliskannya dalam bentuk skripsi serta jurnal yang berjudul "Analisis Putusan Pembatalan Perjanjian Perdamaian Homologasi Pada Kasus Kepailitan PT Njonja Meneer (Studi Kasus: Putusan Pengadilan Niaga Semarang Nomor 11/Pdt.SusPailit/2017/PN Niaga Smg. jo. Putusan Mahkamah Agung Nomor 1397 K/Pdt.Sus-Pailit/2017)".

\section{B. Metode Penelitian}

1. Jenis Penelitian

Metode yang Penulis gunakan dalam penelitian ini adalah dengan meneliti bahan-bahan kepustakaan utuk memecahkan permasalahan hukum yang dibahas agar dapat memberikan preskripsi tentang apa yang seharusnya terjadi dan dibutuhkan sumber-sumber penelitian. Jenis penelitian ini disebut dengan Metode Penelitian Normatif. ${ }^{\text {) }}$

2. Sifat Penelitian

Sifat penelitian ini adalah preskriptif, dimana penelitian ini bersifat menunjukkan alasan mengapa dilakukan penelitian dan memberikan preskripsi mengenai apa yang seharusnya merupakan esensial dari penelitian hukum. ${ }^{7)}$ Sebagai ilmu yang bersifat preskriptif, Ilmu Hukum mempelajari nilai-nilai keadilan, tujuan hukum, norma-norma hukum, konsep-konsep hukum, tujuan hukum dan validitas aturan hukum. ${ }^{8)}$

\section{Jenis Data}

Jenis dan sumber bahan hukum yang akan digunakan dalam penelitian ini adalah:

6) Peter Mahmud Marzuki, Penelitian Hukum, (Jakarta: Kencana Prenada Media Group, 2005), hal. 93.

7) ibid., Cetakan ke-8, hal. bab 6

8) Mukti Fajar dan Yulianto Achmad, Dualisme Penelitian Hukum Normatif dan Empiris, (Yogyakarta: Pustaka Pelajar, 2015), hal. 22. 
a. Bahan Hukum Primer

Yang tergolong sebagai bahan hukum primer adalah bahan hukum yang bersifat autoritatif yaitu mempunyai otoritas. Antara lain adalah peraturan perundang-undangan dan putusan-putusan hakim. ${ }^{9)}$ Bahan hukum primer yang Penulis gunakan di dalam penulisan ini antara lain: Undang-Undang Nomor 37 Tahun 2004 tentang Kepailitan dan Penundaan Kewajiban Pembayaran Utang, Kitab Undang-Undang Hukum Perdata, dan putusan Nomor: 11/Pdt.Sus-PKPU/2017/PN Niaga Smg jo. Nomor: 01/Pdt.Sus-PKPU/2015/PN Niaga Smg.

b. Bahan Hukum Sekunder

Tentunya bahan hukum primer tersebut membutuhkan dukungan bahan hukum sekunder. Contoh dari bahan hukum sekunder adalah bukubuku hukum termasuk skripsi, tesis, disertasi hukum dan jurnal-jurnal hukum adalah bahan hukum sekunder yang utama, ${ }^{10)}$ lebih lanjut lagi terdapat bahan perkuliahan dan artikel yang juga termasuk dalam jenis bahan hukum sekunder.

c. Bahan Non-Hukum

Bahan hukum primer dan bahan hukum sekunder juga memerlukan penujang, hal yang menunjang ini bahan-bahan tersebut adalah bahan non hukum atau yang biasa didefiniaikan sebagai bahan pelengkap serta memberikan petunjuk tambahan, misalya Kamus Besar Bahasa Indonesia (KBBI), ensiklopedia dan pendapat hukum yang telah dirangkum dari hasil wawancara dengan narasumber (ahli hukum) tentang objek yang diteliti.

4. Teknik Pengumpulan Data

\footnotetext{
9) Peter Mahmud, Op.Cit., Cetakan ke-4, hal. 141.

10) ibid., hal. 141.
} 
Dari pemilihan metode penelitian tersebut diatas, maka studi dokumen atau studi pustakalah yang dijadikan sebagai teknik pengumpulan data oleh Penulis. Hal ini dilakukan dengan mengumpulkan bahan-bahan hukum dari bahan hukum primer, sekunder dan bahan non hukum. Selain itu, untuk mendukung penelitian, hasil dari wawancara atau pendapat hukum pihakpihak terkait juga merupakan teknik pengumpulan data yang dilakukan oleh Penulis.

\section{Teknik Analisis Data}

Untuk memperoleh jawaban singkat yang dirumuskan secara deduktif, teknik analisis data yang Penulis gunakan adalah analisis normatif kualitatif, yaitu menguraikan dan menginterpretasikan data dalam bentuk kalimat yang baik dan benar. ${ }^{11)}$ Hasil penelitian ini nantinya akan diurutkan secara sistematis dari hal-hal yang bersifat umum sampai yang bersifat khusus dan disusun dalam bentuk kalimat yang sistematis, jelas dan rinci untuk menjawab pokok bahasan yang ada, hal ini sesuai dengan analisi data kualitatif. Melalui proses berpikir ilmiah dengan logika deduktif atau disebut berpikir analitik yaitu cara berpikir yang bertolak dari peristiwa atau kelompok/jenis, berlaku juga bagi tiap-tiap unsur di dalam peristiwa kelompok/jenis tersebut. ${ }^{12)}$

\section{Rumusan Masalah}

Berdasarkan latar belakang yang telah diuraikan sebelumnya maka permasalahan yang Penulis bahas adalah:

1. Apakah PT Njonja Meneer melakukan wanprestasi terhadap kewajibannya sehingga mengakibatkan perjanjian perdamaian homologasi tersebut dinyatakan batal beserta semua akibatnya?

11) Soerjono Soekanto, Pengantar Penelitian Hukum, (Jakarta: UI Press, 1986), hal. 10.

${ }^{12)}$ Mukti Fajar dan Yulianto Achmad, Op. Cit., hal. 110. 
Analisis Putusan Pembatalan Perjanjian Perdamaian Homologasi Pada Kasus Kepailitan PT Njonja Meneer

(Studi Kasus: Putusan Pengadilan Niaga Semarang Nomor 11/Pdt.Sus-Pailit/2017/Pn Niaga Smg. Jo.

Putusan Mahkamah Agung Nomor 1397 K/Pdt.Sus-Pailit/2017)

2. Bagaimana perlindungan hukum terhadap debitur yang beritikad baik dalam rangka pemenuhan perjanjian perdamaian homologasi tersebut?

\section{PEMBAHASAN}

\section{A. Posisi Kasus}

Kasus ini dimulai pada 27 Januari 2015, dimana Pengadilan Niaga pada Pengadlan Negeri Semarang menjatuhkan putusan Nomor 1/Pdt.SusPKPU/2015/PN Niaga Smg yang berisi pengabulan permohonan penundaan kewajiban pembayaran utang (PKPU) yang diajukan oleh PT Citra Sastra Grafika dan PT Nata Meridian Investara kepada PT Njonja Meneer.

Kemudian dalam proses PKPU Sementara, Majelis Hakim Pengadilan Niaga menerbitkan Penetapan Nomor 1/Pdt.Sus-PKPU/2015/PN Niaga Smg pada tanggal 11 Maret 2015 tentang perpanjangan waktu penundaan kewajiban pembayaran utang dimana pengadilan mengabulkan permohonan pengurus untuk perpanjangan waktu penundaan kewajiban pembayaran utang selama 90 (sembilan puluh) hari terhitung sejak Rabu 11 Maret 2015 sampai dengan Senin 8 Juni 2015.

Pada rapat tanggal 27 Mei 2015, debitur dengan beritikad baik mengajukan Proposal Perdamaian yang ditandatangani oleh debitur in person dan telah disetujui oleh Tim Pengurus dan pada rapat yang dipimpin oleh Hakim Pengawas tersebut, Tim Pengurus melakukan proses pemungutan suara atas proposal perdamaian tersebut dan hasil yang didapat atas pemungutan suara tersebut secara aklamasi semua kreditur telah menyetujui proposal perdamaian yang diajukan oleh deditur.

Berdasarkan hal tersebut, Hakim Pengawas merekomendasikan kepada Majelis Hakim Pengadilan Niaga pada Pengadilan Negeri Semarang untuk mempertimbangkan agar Proposal Perdamaian Debitur PT Njonja Meneer 
Analisis Putusan Pembatalan Perjanjian Perdamaian Homologasi Pada Kasus Kepailitan PT Njonja Meneer (Studi Kasus: Putusan Pengadilan Niaga Semarang Nomor 11/Pdt.Sus-Pailit/2017/Pn Niaga Smg. Jo. Putusan Mahkamah Agung Nomor 1397 K/Pdt.Sus-Pailit/2017)

diterima dan dihomologasi. Pada akhirnya, Proposal Perdamaian tanggal 27 Mei 2015 tersebut disahkan pada hari Senin, 8 Juni 2015.

Jumlah tagihan Kreditur yang diakui pengurus adalah sebesar Rp. 198.471.760.917,- dan bahwa dalam Rencana Perdamaiannya, pembayaran dilakukan sebagai berikut:

1. Kreditur Preferen, yaitu kantor KPP Madya Semarang sebesar Rp. 20.838.531.389,- dan KPP Gayam Semarang sebesar Rp. 500.000,- akan dibayarkan sesuai dengan peraturan perundang-undangan yang berlaku.

2. Kreditur Separatis, yaitu BANK PAPUA sebesar Rp. 68.200.000.000,pembayarannya sesuai jadwal sebagaimana diperjanjikan dalam perjanjian kredit bank.

3. Kreditur Konkuren, cara pembayarannya dibagi menjadi 7 kelompok yang cara pembayarannya dicicil dimulai akhir bulan Juli 2015, yaitu sebagai berikut:

a. Jumlah utang sampai dengan Rp. 100.000.000 (seratus juta rupiah) dicicil selama 1 (satu) tahun, dimulai akhir bulan Juli 2015 hingga bulan Juni 2016;

b. Jumlah utang diatas Rp. 100.000.000 (seratus juta rupiah) sampai dengan Rp. 350.000.000 (tiga ratus lima puluh juta rupiah) dicicil selama 2 (dua) tahun, dimulai akhir bulan Juli 2015 hingga bulan Juni 2017 ;

c. Jumlah utang diatas Rp. 350.000 .000 (tiga ratus lima puluh juta rupiah) sampai dengan Rp. 750.000 .000 (tujuh ratus lima puluh juta rupiah) dicicil selama 3 (tiga) tahun, dimulai akhir bulan Juli 2015 hingga bulan Juni 2018;

d. Utang kepada Koperasi Srikaton akan dicicil setiap bulan dalam jangka waktu 3 (tiga) tahun; 
e. Utang kepada PT Nata Meridian Investara akan diselesaikan dengan cara mencicil setiap bulannya untuk jangka waktu 3 (tiga) tahun, dimulai sejak 29 Juli 2015 hingga 29 Juni 2018 sesuai dengan Akta Perjanjian Perdamaian No. 26 tanggal 27 April 2015;

f. Jumlah utang diatas Rp. 750.000 .000 (tujuh ratus lima puluh juta rupiah) sampai dengan Rp. 5.000.000.000 (lima milyar rupiah) dicicil selama 4 (empat) tahun, dimulai akhir bulan Juli 2015 hingga bulan Juni 2019;

g. Utang kepada karyawan akan dicicil selama 4 (empat) tahun, setiap bulannya;

h. Jumlah utang diatas Rp. 5.000.000.000 (lima milyar rupiah) sampai dengn Rp. 35.000.000.000 (tiga puluh lima milyar rupiah) dicicil selama 5 (lima) tahun, dimulai akhir bulan Juli 2015 hingga bulan Juni 2020.

\section{Dasar Pembatalan Perjanjian Perdamaian Homologasi}

Pada tanggal 20 Juni 2017, salah satu kreditur PT Njonja Meneer, Hendrianto Bambang Santoso, mengajukan surat permohonan pembatalan perjanjian perdamaian hom...........ologasi dibawah register Nomor 11/Pdt.Sus-Pailit/2017/PN Niaga Smg jo. Nomor 1/Pdt.Sus-PKPU/2015/PN Niaga Smg.

Pada intinya, Hendrianto mempermasalahkan bahwa dalam Putusan Perjanjian Perdamaian Homologasi, PT Njonja Meneer memiliki kewajiban untuk mencicil / membayar selama 5 (lima) tahun yakni dimulai dari akhir Juli 2015 hingga akhir Juni 2020, dan ia mempermasalahkan bahwa seharusnya jika dihitung sejak akhir Juli 2015 hingga Permohonan Pembatalan ini, PT Njonja Meneer seharusnya sudah menyelesaikan total cicilan sebanyak 24 (dua puluh empat) kali jika dihitung dari Juli 2015 hingga 
Mei 2017. Sehingga ia mempermasalahkan PT Njonja Meneer tidak melaksanakan pencicilan sesuai kesepakatan yang sudah ditetapkan dalam Proposal Perdamaian yakni sebesar Rp. 7.040.970.500,- (tujuh miliar empat puluh juta sembilan ratus tujuh puluh ribu lima ratus rupiah).

Selain itu, Hendrianto mengatakan bahwa PT Njonja Meneer telah menyerahkan 10 (sepuluh) lembar cek yang kesemuanya tidak dapat dicairkan karena rekening ditutup meskipun PT Njonja Meneer telah memberitahukan melalui surat yang dikirimkan oleh PT Njonja Meneer kepada Hendrianto pada tanggal 15 Juni 2015.

Pada kenyataannya, tidak semua bilyet giro yang diajukan oleh PT Njonja Meneer tidak bisa dicairkan, selain itu PT Njonja Meneer juga ada melakukan pembayaran dengan pengiriman uang (Bukti T-5 s/d T-18) yang betul adanya dan diakui oleh Hendrianto sendiri. Selain itu, klausul dari pelunasan hutang tersebut tidak menyebutkan pencicilannya dilakukan setiap bulan. Melainkan "Jumlah utang diatas Rp. 5.000.000.000 (lima milyar rupiah) sampai dengn Rp. 35.000.000.000 (tiga puluh lima milyar rupiah) dicicil selama 5 (lima) tahun, dimulai akhir bulan Juli 2015 hingga bulan Juni 2020.”

Hendrianto mengatakan bahwa karena jumlah utangnya yang baru terbayar hanya sejumlah Rp. 412.094 .000 (empat ratus dua belas juta sembilan puluh empat ribu rupiah) dalam kurun waktu 2 tahun dan penolakan sebagian bilyet giro oleh Bank Penerbit (PT Bank Central Asia Tbk., KCU Solo) dengan alasan saldo tidak cukup ini merupakan suatu kelalaian, sehingga ia memohon pembatalan perjanjian perdamaian tersebut.

\section{Putusan Pengadilan Niaga Nomor 11/Pdt.Sus-Pailit/2017/PN Niaga Smg jo. Nomor 1/Pdt.Sus-PKPU/2015/PN Niaga Smg}

Pada akhirnya, Pengadilan Niaga pada Pengadilan Negeri Semarang dalam putusannya Nomor 11/Pdt.Sus-Pailit/2017/PN Niaga Smg jo. Nomor 
Indah Jacinda \& S. Atalim

Analisis Putusan Pembatalan Perjanjian Perdamaian Homologasi Pada Kasus Kepailitan PT Njonja Meneer

(Studi Kasus: Putusan Pengadilan Niaga Semarang Nomor 11/Pdt.Sus-Pailit/2017/Pn Niaga Smg. Jo.

Putusan Mahkamah Agung Nomor 1397 K/Pdt.Sus-Pailit/2017)

1/Pdt.Sus-PKPU/2015/PN Niaga Smg memutuskan bahwa Perjanjian

Perdamaian Homologasi Nomor 1/Pdt.Sus-PKPU/2015/PN Niaga Smg tanggal 8 Juni 2015 dibatalkan dan PT Njonja Meneer pailit dengan segala akibat hukumnya.

\section{Kasasi pada Mahkamah Agung}

Setelah Putusan Pengadilan Niaga pada Pengadilan Negeri Semarang tersebut dibacakan pada tanggal 3 Agustus 2017, PT Njonja Meneer mengajukan permohonan Kasasi pada tanggal 10 Agustus 2017. Isi Kontra Memori Kasasinya secara singkat adalah sebagai berikut:

1. Bahwa menurut debitur, dengan tidak mempertimbangkannya bukti di persidangan mengenai proposal perdamaiannya, karena Proposal Perdamaian yang digunakan bukanlah proposal perdamaian yang benar, dimana proposal yang telah disahkan oleh Pengadilan Niaga pada Pengadilan Negeri Semarang adalah proposal perdamaian tanggal $27 \mathrm{Mei}$ 2015 dan bukan Proposal Perdamaian 5 maret 2015, sehingga proposal Perdamaian 5 Maret 2015 (bukti P-1) seharusnya tidak bisa dijadikan bukti maupun acuan dalam pembayaran, sehingga menurut Pemohon, Judex Facti sangat keliru dan melakukan kelalaian dalam memeriksa dan memutus perkara ini. Judex Facti telah bersikap ambivalen dan tidak memberikan keadilan dan kepastian hukum.

2. Mengenai pertimbangan hakim yang menyatakan jumlah pembayaran tidak sebanding (tidak signifikan), dan menyatakan bahwa penutupan rekening yang diblokir oleh pihak bank menandakan PT Njonja Meneer dalam keadaan lalai bahkan tidak mampu membayar tanpa perlu melihat batas akhir pembayaran dalam perjanjian yaitu tahun 2020, PT Njonja Meneer mengatakan bahwa Judex Facti lalai dan tidak mempertimbangkan bukti di persidangan bahwa PT Njonja Meneer 
beritikad baik dalam melaksanakan perdamaian tersebut yang dibuktikan dengan jumlah pembayaran dengan pengiriman uang (Bukti T-5 s/d T18), bahkan 2 (dua) hari setelah diajukannya permohonan pembatalan perjanjian perdamaian tersebut, debitur masih melakukan pembayaran kewajibannya. Selain itu, dalam kontra memori kasasinya, PT Njonja Meneer menyebutkan bahwa pihaknya tidak bisa dikatakan lalai maupun wanprestasi dalam pemenuhan kewajibannya karena pihaknya tidak sekalipun menerima surat teguran maupun surat peringatan (somasi) dari kreditur bahwa pihaknya lalai dalam memenuhi kewajibannya. Lebih lanjut, perjanjian perdamaian homologasi tersebut masih berakhir pada bulan Juli 2020, sehingga PT Njonja Meneer tidak bisa dikatakan lalai maupun wanprestasi dikarenakan perjanjian tersebut belum jatuh tempo yang berarti tuntutan Termohon Kasasi adalah prematur (terlalu dini).

3. Bahwa Menurut PT Njonja Meneer, Judex Facti seharusnya memberikan kelonggaran kepada Pemohon Kasasi dalam waktu 30 (tiga puluh) hari untuk memenuhi kewajibannya setelah diucapkannya putusan pemberian kelonggaran apabila terdapat utang yang dimiliki Pemohon Kasasi kepada Termohon Kasasi, hal ini sesuai dengan Pasal 170 (3) UUK PKPU. Sehingga dengan tidak menjalankan dan tidak sesuai dengan Pasal 170 UUK PKPU tersebut menurutnya, Judex Facti salah menerapkan hukum dalam memutus pembatalan perdamaian dan pernyataan pailit karena tidak sesuai dengan ketentuan Pasal 170 UUK PKPU. Terlebih lagi dalam perkara a quo Judex Facti belum pernah memberikan atau menjatuhkan putusan pemberian kelonggaran kepada Pemohon Kasasi. Lebih lanjut, menurut PT Njonja Meneer seharusnya pengadilan mempertimbangkan kepailitan sebagai ultimum remedium dan mempertimbangkan bahwa PT Njonja Meneer bukanlah Debtor hopelessly in debt karena perusahaan 
Analisis Putusan Pembatalan Perjanjian Perdamaian Homologasi Pada Kasus Kepailitan PT Njonja Meneer

(Studi Kasus: Putusan Pengadilan Niaga Semarang Nomor 11/Pdt.Sus-Pailit/2017/Pn Niaga Smg. Jo.

Putusan Mahkamah Agung Nomor 1397 K/Pdt.Sus-Pailit/2017)

tersebut masih memiliki prospek yang baik dan potensi untuk berkembang dan masih mampu membayar seluruh kewajibannya.

4. Bahwa Judex Facti telah salah menerapkan hukum karena bertentangan dengan tujuan hukum serta maksud kepailitan dan nilai-nilai keadilan. Bahwa dalam mukadimah penjelasan Undang-Undang Kepailitan dan PKPU ada dikenal Asas Keseimbangan dan Asas Kelangsungan Usaha yang dimana dapat disimpulkan bahwa kepailitan ini sesungguhnya hadir dengan tujuan untuk melindungi hak-hak debitur dan para kreditur dengan itikad baik, serta kepailitan memiliki maksud dan tujuan agar lembaga kepailitan tidak digunakan secara tidak bertanggung jawab, dan agar tetap memperhatikan usaha debitur terlebih lagi debitur yang masih prospektif san dapat membayar utang-utangnya agar tidak serta merta dinyatakan pailit.

5. Bahwa dalam Kontra Memori Kasasinya, PT Njonja Meneer menyebutkan bahwa putusan pembatalan perjanjian perdamaian ini menyebabkan ketidakpastian hukum bagi para kreditur yang dari awal menyepakati Perjanjian Perdamaian tersebut karena dengan disetujui dan disahkannya perjanjian itu merupakan lambang bahwa kreditur percaya terhadap debitur dan bahwa para kreditur sepakat tidak akan menaruh debitur dalam pailit atau keadaan pailit. Hal ini berarti menurutnya melambangkan bahwa, Judex Facti, telah lalai dalam memeriksa dan mengadili perkara a quo karena tidak mempertimbangkan fakta perlunya kepastian hukum bagi kreditur konkuren lain. Selain itu dituliskan bahwa hal ini akan menyebabkan contoh yang kurang baik dalam dunia perekonomian dan hukum kusunya dalam hal kepastian hukum di Indonesia, serta khususnya bagi para kreditur konkuren PT Njonja Meneer menjadi bagian serta terdaftar dalam perjanjian perdamaian 
tersebut serta membawa implikasi ekonomi dan hukum yang besar serta kepada +1.000 ribu karyawan PT Njonja Meneer.

6. Bahwa dengan tidak mempertimbangkan dan menunjuk kurator yang diajukan oleh debitur selaku pemilik aset, Pemohon kasasi menganggap bahwa Judex Facti telah lalai dan salah menerapkan hukum dalam memeriksa dan mengadili perkara a quo.

\section{Putusan Mahkamah Agung Nomor Nomor 1397 K/Pdt.Sus-Pailit/2017}

Terhadap keberatan yang diajukan oleh Pemoho Kasasi, Mahkamah Agung berpendapat bahwa keberatan yang diajukan tersebut tidak dapat dibenarkan dan dalam hal ini Pengadilan Niaga pada Pengadilan Negeri Semarang tidak salah menerapkan hukum dan Putusan Pengadilan Niaga pada Pengadilan Negeri Semarang Nomor 11/Pdt.Sus-Pailit/2017/PN Niaga Smg jo. Nomor 1/Pdt.Sus-PKPU/2015/PN Niaga Smg tidak bertentangan dengan hukum dan/atau undang-undang, sehingga permohonan kasasi PT Njonja Meneer tersebut harus ditolak.

\section{B. Apakah PT Njonja Meneer melakukan wanprestasi terhadap kewajibannya sehingga mengakibatkan perjanjian perdamaian homologasi tersebut dinyatakan batal beserta semua akibatnya?}

Sesuai dengan apa yang sudah dibahas sebelumnya, dalam PKPU dikenal adanya suatu usaha perdamaian yaitu dengan membuat perjanjian perdamaian, Munir Fuady dalam bukunya menjelaskan bahwa "kata sepakat" sesungguhnya adalah kunci dari sebuah perjanjian, apabila suatu pertikaian ingin deselesaikan melalui perjanjian perdamaian, maka diperlukan adanya "kata sepakat" antara para pihak yang bertikai. Perdamaian dalam proses kepailitan ini sendiri mengantongi arti yang sama dengan perdamaian pada umumnya karena memiliki prinsip yang sama. Perdamaian dalam Penundaan 
Kewajiban Pembayaran Utang itu sendiripun diatur dalam Pasal 265 UUK PKPU dimana dalam pasal tersebut dituliskan bahwa "debitur memiliki hak untuk menawarkan suatu perdamaian kepada kreditur-krediturnya meskipun setelah mengajukan permohonan penundaan kewajiban pembayaran utang".

Setelah disepakati antara debitur dan para krediturnya, agar perjanjian ini dapat dijalankan maka diperlukan adanya suatu pengesahan atau yang disebut dengan homologasi, dalam wawancaranya, Kurator PT Njonja Meneer Bapak Wahyu Hidayat, S.H., menjelaskan homologasi adalah pengesahan perdamaian oleh majelis hakim atas kesepakatan yang dibuat oleh debitur dan kreditur-krediturnya mengenai cara pelunasan utang-utang debitur. ${ }^{13)}$

Setelah perjanjian tersebut dihomologasi, maka terdapat kewajiban yang harus dipenuhi oleh debitur terhadap kreditur-krediturnya, tentu saja perjanjian perdamaian ini memiliki konsekuensi yaitu sekalipun telah disepakati oleh debitur dan para krediturnya, suatu saat debitur terbukti melakukan cidera janji, maka debitur secara otomatis dinyatakan pailit oleh pengadilan. Hal ini disebutkan dalam Pasal 170 Ayat 1 UUK PKPU yang menyebutkan "Pembatalam suatu perdamaian dapat diajukan oleh kreditur apabila Debtur lalai dalam pemenuhan isi perdamaian tersebut". Apabila kita melihat pada bagian penjelasan dari undang-undang tersebut maka tidak ada definisi lebih lanjut dari kriteria lalai yang dimaksud dalam pemenuhan kewajiban dari perdamaiannya tersebut.

Namun, definisi "lalai" dalam KUH Perdata tercantum dalam Pasal 1238 dimana dituliskan bahwa "Si berutang adalah lalai, apabila ia dengan surat perintah atau dengan sebuah akta sejenis itu telah dinyatakan lalai, atau demi perikatan sendiri, ialah jika ini menetapkan bahwa si berutang harus dianggap lalai dengan lewatnya waktu yang ditentukan". Sehingga dapat disimpulkan

${ }^{13)}$ Peneliti, Wawancara, dengan Kurator PT Njonja Meneer, (Jakarta: Kantor Hukum WA \& Partners, 28 Januari 2019). 
Analisis Putusan Pembatalan Perjanjian Perdamaian Homologasi Pada Kasus Kepailitan PT Njonja Meneer (Studi Kasus: Putusan Pengadilan Niaga Semarang Nomor 11/Pdt.Sus-Pailit/2017/Pn Niaga Smg. Jo. Putusan Mahkamah Agung Nomor 1397 K/Pdt.Sus-Pailit/2017)

bahwa kelalaian dalam KUHPerdata adalah apabila debitur tidak memenuhi suatu prestasi yang diperjanjikannya dan telah jatuh tempo serta dapat ditagih dan sudah menerima peringatan dari kreditur.

Lebih lanjut, R. Subekti mengkategorikan wanprestasi atau yang disebut dengan kelalaian atau kealpaan seorang debitur dalam 4 (empat) macam yaitu: ${ }^{14)}$

a. Tidak melakukan sesuatu sesuai dengan kesepakatan yang disanggupinya;

b. Meskipun melakukan yang dijanjikannya, hal tersebut tidak sesuai dengan apa yang dijanjikan;

c. Meskipun melakukan yang dijanjikannya, hal tersebut dilakukan terlambat;

d. Melakukan hal yang tidak boleh dilakukannya.

Hal tersebut sesuai dengan Pasal 1234 KUHPerdata, yang menuliskan bahwa ada tiga macam wujud prestasi yaitu, memberikan sesuatu, melakukan sesuatu dan tidak melakukan sesuatu.

Dalam pertimbangan putusan pembatalan perjanjian perdamaiannya, PT Njonja Meneer dikatakan lalai memenuhi kewajibannya. Apabila kita melihat dalam pertimbangan putusannya, Pengadilan Negeri Semarang mempertimbangkan sebagai berikut:

1. Bahwa terdapat penghilangan frasa "dengan cara mencicil untuk setiap bulannya" menjadi "dicicil selama 5 (lima) tahun dimulai akhir Juli 2015 hingga Juni 2020" dan secara de facto Termohon dalam melakukan kewajiban pembayaran dilakukan dengan cara mencicil dalam setiap bulannya (bukti T-5 s/d T-18); Kenyataan tersebut membuktikan bahwa

14) Salim M.S, Hukum Kontrak : Teori dan Teknik Penyusunan Kontrak, (Jakarta: Sinar Grafika, 2010), hal. 99. 
Analisis Putusan Pembatalan Perjanjian Perdamaian Homologasi Pada Kasus Kepailitan PT Njonja Meneer

(Studi Kasus: Putusan Pengadilan Niaga Semarang Nomor 11/Pdt.Sus-Pailit/2017/Pn Niaga Smg. Jo.

Putusan Mahkamah Agung Nomor 1397 K/Pdt.Sus-Pailit/2017)

Termohon menyadari dan memahami kewajiban pembayaran cicilan ditentukan secara periodik setiap bulannya selama 5 (lima) tahun.

2. Jumlah pembayaran yang sudah diterima dengan total Rp. 412.094.000,(empat ratus dua belas juta sembilan puluh empat ribu rupiah) tidak sebanding (tidak signifikan) dengan kewajiban pembayaran sejumlah Rp.7.040.970.500,- (tujuh miliar empat puluh juta sembilan ratus tujuh puluh ribu lima ratus rupiah).

3. Bahwa pembayaran dengan menerbitkan Bilyet Giro (P-3.1. s/d P-3.8.), akan tetapi keseluruhan bilyet giro tersebut, dengan alasan rekening telah ditutup yang menyebabkan tidak dapat dicairkan karena diblokir oleh pihak bank, menurut Majelis Hakim, membuktikan bahwa PT Njonja Meneer telah dalam keadaan lalai memenuhi kewajiban pembayaran kepada Termohon, bahkan lebih jauh membuktikan Termohon tidak lagi dalam keadaan mampu membayar, dan keadaan berhenti membayar tersebut telah cukup untuk menyatakan Termohon dalam keadaan lalai, tanpa harus menunggu batas waktu pembayaran berakhir (tahun 2020).

Ada beberapa hal yang Penulis tidak setuju dengan pertimbangan Majelis Hakim pada Pengadilan Negeri Semarang tersebut, antara lain yang pertama, meskipun secara de facto PT Njonja Meneer melakukan pembayaran kewajibannya setiap bulannya, hal tersebut tidak berarti mengubah kenyataan pada perjanjian perdamaian homologasi itu sendiri dimana jelas disebutkan bahwa “... h. Jumlah utang diatas Rp. 5.000.000.000 (lima milyar rupiah) sampai dengn Rp. 35.000.000.000 (tiga puluh lima milyar rupiah) dicicil selama 5 (lima) tahun, dimulai akhir bulan Juli 2015 hingga bulan Juni 2020.”

Yang berarti pembayaran bebas dilakukan kapanpun dalam jangka waktu 5 tahun tersebut karena tidak disebutkan termin waktunya. Serta meningat perjanjian perdamaian tersebut dibuat atas dasar kesepakatan, maka mengemai termin waktu yang telah ditentukan tersebut merupakan termin waktu yan 
telah disepakato sebelumya. Berikutnya Penulis setuju dengan pendapat Kuasa Hukum PT Njonja Meneer, Bapak La Ode Kudus, S.H., yang pada saat wawancara ${ }^{15)}$ menyebutkan bahwa siapakah sesungguhnya yang melakukan penghilangan frasa tersebut, sehingga hal tersebut terlihat cukup mengadangada. Karena pada perjanjiannya itu sendiripun tidak pernah ada kata "dicicil setiap bulannya" hanya ada "dicicil selama 5 (lima) tahun".

Yang kedua, Mengenai ketidak-signifikanan, Penulis mengutip hasil wawancara dengan Dr. Munir Fuady, S.H., M.H., L.L.M., selaku Kurator, Penulis Buku Kepailitan \& Dosen Fakultas Hukum UNTAR, beliau menyatakan bahwa alasan tidak sebanding atau tidak signifikan bukanlah suatu syarat wanprestasi, kecuali pada saat jatuh tempo, jumlah utang yang dibayarkan tidak terpenuhi baru bisa seorang debitur dikatakan lalai atau wanprestasi. ${ }^{16)}$

Lebih lanjut, menurut Penulis, perjanjian perdamaian homologasi tersebut belum berakhir jangka waktunya karena masih berakhir di tahun 2020, seharusnya PT Njonja Meneer tidak bisa dikatakan lalai karena dalam hukum perdata dikenal yang namanya Prestasi. Prestasi sebagai kewajiban dari apa yang harus dilakukan dan dijalankan oleh debitur dalam sebuah perikatan ini, merupakan isi dari perjanjian dalam perikatan tersebut. Debitur akan dikatakan melakukan wanprestasi tidak dapat menjalankan kewajibannya sesuai dengan perjanjian yang telah ditentukan. ${ }^{17)}$ Yang berarti dalam kasus ini, PT Njonja Meneer tidak bisa dikatakan telah melakukan wanprestasi.

Ketiga, mengenai beberapa Bilyet Giro yang diterbitkan PT Njonja Meneer memang tidak bisa dicairkan sesuai dengan Bukti (P-3.1. s/d P-3.8.),

${ }^{15)}$ Peneliti, Wawancara, dengan Kuasa Hukum PT Njonja Meneer, (Jakarta: JK Law Offices, 1 Desember 2018).

16) Peneliti, Wawancara, (Jakarta: Fakultas Hukum Universitas Tarumanagara, 28 Desember 2018). hal. 218 .

\footnotetext{
17) Riduan Syahrani, Seluk-Beluk dan Asas-Asas Hukum Perdata, (Bandung: Alumni, 2006),
} 
tetapi hal itu juga sudah diketahui PT Njonja Meneer dan sudah diberikan pemberitahuan kepada kreditur nya dalam Bukti P-3.9., maka dari itu, setelah diberitahu, PT Njonja Meneer melakukan pembayaran menggunakan pengiriman uang, Bukti (T-5 s/d T-18). Bukti pembayaran ini pun diterima dan diakui oleh kreditur tersebut.

Sehingga menurut Penulis, pertimbangan Majelis Hakim yang mengatakan "bahwa PT Njonja Meneer telah lalai dalam dalam menjalankan kewajiban pembayarannya kepada Termohon dan PT Njonja Meneer menunjukkan bahwa dirinya dalam keadaan tidak mampu membayar, dan peristiwa berhenti membayar yang sempat terjadi itu cukup untuk memyuatakan bahwa PT Njonja Meneer dalam keadaan lalai tanpa harus menunggu akhir dari waktu pembayaran dalam perjanjian itu yaitu tahun 2020" adalah tidak tepat.

Hakim tidak melihat bahwa unsur dari kelalaian itu sendiri saja tidak terpenuhi. kelalaian dalam KUHPerdata seperti yang sudah dijelaskan sebelumnya adalah apabila debitur tidak memenuhi suatu prestasi yang diperjanjikannya dan telah jatuh tempo serta dapat ditagih dan sudah menerima peringatan dari kreditur. Pada kenyataan kasus ini, perjanjian perdamaiannya belum jatuh tempo dan tidak dapat dapat ditagih, apalagi menerima peringatan atau somasi dari kreditur. Hakim juga tidak melihat bahwa debitur bukanlah debtor hopelessly in debt, karena masih adanya prospek yang baik dan potensi perusahaan debitur untuk berkembang dan diyakini masih dapat melakukan kewajibannya terhadap seluruh krediturnya di masa yang akan mendatang. 
Analisis Putusan Pembatalan Perjanjian Perdamaian Homologasi Pada Kasus Kepailitan PT Njonja Meneer (Studi Kasus: Putusan Pengadilan Niaga Semarang Nomor 11/Pdt.Sus-Pailit/2017/Pn Niaga Smg. Jo. Putusan Mahkamah Agung Nomor 1397 K/Pdt.Sus-Pailit/2017)

Lebih lanjut, menurut Penulis, Majelis Hakim tidak mempertimbangkan asas-asas hukum kepailitan dalam pertimbangannya, asas-asas yang menurut penulis tidak di pertimbangkan tersebut adalah: ${ }^{18)}$

\section{a. Asas Keseimbangan}

Dalam undang-undang ini terdapat tujuan pencegahan penyalahgunaan kepailitan dan lembaga kepailitan oleh kreditur yang beritikad tidak baik, dan tidak jujur mengingat pentingnya menjaga keseimbangan tujuan dari kepailitan dan usaha debitur itu sendiri.

b. Asas Kelangsungan Usaha

Majeli hakim harus mempertimbangkan kelangsungan usaha debitur dan dapat terlihatdalam undang-undang kepailitan itu sendiri terdapat ketentuan yang melindungi debitur dan memungkinkan perusahaan Debitur yang prospektif tetap dapat dilangsungkan.

c. Asas Keadilan

Asas ini mengandung arti bahwa rasa keadilan harus ada dan terpenuhi bagi para pihak. Asas ini sesungguhnya untuk mencegah kesewenangan terhadap debitur, khususnya mencegah pihak penagih yang tidak memperdulikan kreditur lainnya dan mengusahakan pembayaran dari tagihannya masing-masing terhadap debitur.

Sehingga, melihat dari tidak dipertimbangkannya asas-asas hukum kepailitan sebagai dasar dibentuknya UUK PKPU itu sendiri, penafsiran Hakim dalam mempertimbangkan putusan ini menurut Penulis adalah cukup subyektif, karena Hakim tidak memperhatikan obyek dari kasus ini yaitu perjanjian perdamaiannya dan pengaturan mengenai hal tersebut. Dan hakim tidak mempertimbangkan kepailitan sebagai ultimum remedium, Yang mana menurut Sutan Remy Sjahdeni dalam bukunya menuliskan, bahwa kepailitan seharusnya dijadikan sebagai satu-

${ }^{18)}$ Rahayu Hartini, Rahayu Hartini Hukum Kepailitan, (Malang: UMM Press, 2007), hal. 1417. 
satunya cara untuk membereskan kewajiban pembayaran dan apabila tidak ada lagi cara lain untuk membereskan kewajibannya tersebut kepada para krediturkrediturnya. Jadi, sebagai hakim harus mempertimbangkan kepailitan itu sendiri sebagai upaya terakhir.

\section{Bagaimana perlindungan hukum terhadap debitur yang beritikad baik dalam rangka pemenuhan perjanjian perdamaian homologasi tersebut?}

Berdasarkan kasus tersebut, PT Njonja Meneer sebagai debitur tidak pernah lalai memenuhi perjanjian perdamaian yang telah dihomologasi. Hal ini dapat dilihat dari pembayaran-pembayaran yang debitur usaha lakukan yaitu dalam bukti T-5 s/d T-18, dengan itikad baik dan penuh tanggung jawab. Debitur melakukan cicilan pembayarannya kepada kreditur tersebut pada saat 2 (dua) hari setelah diajukan permohonan pembatala, pada saat itu, debitur belum menerima relaas pemberitahuan sidang atau pemberitahuan mengenai adanya perkara tersebut dari Pengadilan Niaga pada Pengadilan Negeri Semarang.

Mengenai Bilyet Giro yang tidak bisa dicairkan tersebut, sudah diketahui PT Njonja Meneer dan dengan itikad baik sudah diberikan pemberitahuan kepada kreditur nya dalam Bukti P-3.9., maka dari itu, setelah diberitahu, PT Njonja Meneer melakukan pembayaran menggunakan pengiriman uang, Bukti (T-5 s/d T-18). Bukti pembayaran ini pun diterima dan diakui oleh kreditur tersebut.

Terhadap para debitur yang beritikad baik dalam rangka pemenuhan perjanjian perdamaian homologasi, sesuai dengan Pasal 170 Ayat 2 UUK PKPU, Seorang debitur berhak dan wajib membuktikan bahwa perdamaian telah terpenuhi, dan bahwa ia memenuhi isi dari kewajibannya tersebut dengan itikad baik. Bila tidak terbukti seorang debitur lalai dalam memenuhi kewajibannya tersebut, maka debitur tidak dapat diklaim lalai dalam pemenuhan kewajiban perjanjiannya. 
Analisis Putusan Pembatalan Perjanjian Perdamaian Homologasi Pada Kasus Kepailitan PT Njonja Meneer (Studi Kasus: Putusan Pengadilan Niaga Semarang Nomor 11/Pdt.Sus-Pailit/2017/Pn Niaga Smg. Jo. Putusan Mahkamah Agung Nomor 1397 K/Pdt.Sus-Pailit/2017)

Lebih lanjut, Penulis mengutip hasil wawancara dengan Kuasa Hukum PT Njonja Meneer, La Ode Kudus, S.H. beliau menyatakan bahwa perlindungan hukum terhadap debitur sendiri adalah dalam bentuk sebuah upaya hukum yaitu kasasi dan peninjauan kembali. Setelah jatuhnya atau diputuskannya putusan atas permohonan pailit oleh Pengadilan Niaga, maka pihak yang merasa dirugikan dapat melakukan upaya hukum terhadap putusan tersebut yatu dengan mengajukan Kasasi ke Mahkamah Agung (Pasal 11 Ayat (1) UUK PKPU).

Pasal 11 ayat (2) UUKPKPU menyebutkan dalam kurun waktu paling lamabat 8 hari dihitung sejak tanggal jatuhnya putusan pengadilam niaga, permohonan kasasi dapat diajukan ke Mahkamah agung dengan melakukam pendaftaram di panitera pengadilan niaga yang menjatuhkan permohonan pernyataan pailit.

Dalam buku Tata Wijayanta disebutkan bahwa Pihak yang masih merasa dirugikam atau tidak puas dengan putusan kasasi boleh mengajukan upaya hukum peninjauan kembali ke Mahkamah Agung. Upaya hukum ini boleh dilakukan, apabila terdapat bukti-bukti baru. Upaya hukum peninjauan kembali ini diatur dalam Pasal 295 sampai Pasal 298 UUK PKPU.

Sangat disayangkan, dalam kasus ini PT Njonja Meneer tidak mendapatkan perlindungan hukum yang maksimal, hal ini dapat dilihat dari Putusan Mahkamah Agung yang juga mendukung Putusan Pengadilan Niaga Semarang. Menurut Penulis, memang perlindungan hukum prosedural telah didapatkan oleh pihak debitur, yaitu penegakan hukum sudah sesuai dengan prosedur dalam peraturan perundang-undangan atau biasa yang disebut dengan "keadilan prosedural". Namun, kehadiran keadilan substansial tersebut tidak ada.

\section{PENUTUP}

\section{A. Kesimpulan}


Kesimpulan yang dihasilkan dari pokok permasalahan yang telah dibahas sebelumnya, adalah:

1. PT Njonja Meneer tidak bisa dikatakan wanprestasi dalam memenuhi kewajiban perjanjian perdamaian homologasi tersebut, karena menurut Pasal 1238 KUH Perdata tercantum bahwa "Si berutang adalah lalai, apabila ia dengan surat perintah atau dengan sebuah akta sejenis itu telah dinyatakan lalai, atau demi perikatan sendiri, ialah jika ini menetapkan bahwa si berutang harus dianggap lalai dengan lewatnya waktu yang ditentukan". Selain itu, kelalaian dalam KUHPerdata adalah apabila debitur tidak memenuhi suatu prestasi yang diperjanjikannya dan telah jatuh tempo serta dapat ditagih dan sudah menerima peringatan dari kreditur. Yang mana dalam kasus ini, PT Njonja Meneer tidak pernah menerima somasi maupun peringatan dari kreditur atas kelalaian yang dianggap dilakukan oleh PT Njonja Meneer, selain itu perjanjian perdamaian pun belum jatuh tempo (masih di tahun 2020), sehingga PT Njonja Meneer tidak bisa dikatakan telah melakukan wanprestasi terhadap kewajibannya;

2. Sesuai dengan Pasal 170 Ayat 2 UUK PKPU, Seorang debitur berhak dan wajib membuktikan bahwa perdamaian telah terpenuhi, dan bahwa ia memenuhi isi dari kewajibannya tersebut dengan itikad baik. Bila tidak terbukti seorang debitur lalai dalam memenuhi kewajibannya tersebut, maka debitur tidak dapat diklaim lalai dalam pemenuhan kewajiban perjanjiannya. Selain itu, perlindungan hukum terhadap debitur sendiri adalah dalam bentuk sebuah upaya hukum yaitu kasasi dan peninjauan kembali. Namun disayangkan, dalam kasus ini PT Njonja Meneer tidak mendapatkan perlindungan hukum yang maksimal, hal ini dapat dilihat dari Putusan Mahkamah Agung yang juga mendukung Putusan Pengadilan Negeri Semarang dan dalam pertimbangannya menuliskan bahwa Pengadilan Negeri Semarang tidak salah menerapkan hukum. 


\section{B. Saran}

Berdasarkan permasalahan dan analisis yang dikemukakan, saran yang dapat Penulis berikan adalah:

1. Undang-Undang Kepailitan dan PKPU harus diperbaharui, karena jika melihat pada proses perdamaiannya, peraturan tersebut seakan-akan lebih menguntungkan pihak kreditur. Hal ini jelas tidak sesuai dengan tujuan diakannya PKPU yaitu untuk mencegah pailitnya debitur, sehingga perlu adanya tolak ukur bagaimana bentuk kelalaian dalam pemenuhan kewajiban perjanjian perdamaian itu sendiri agar pembatalan perjanjian perdamaian dalam PKPU tidak digunakan oleh kreditur yang beritikad tidak baik;

2. Hakim yang dianggap sebgai sumber keadilan dan tempat para pihak mencari keadilan, dalam mengambil keputusan, haruslah juga mempertimbangkan Tujuan dan Nilai-Nilai dari Undang-Undang Kepailitan dan PKPU itu sendiri hal ini harus dilakukan agar kepailitan tidak digunakan sebagai senjata oleh kreditur yang beritikad tidak baik karena kepailitan itu adalah sebuat ultimum remedium, yaitu upaya terakhir untuk melindungi usaha debitur.

\section{DAFTAR PUSTAKA}

\section{Buku-buku:}

Widijowati, Dijan. Hukum Dagang. (Yogyakarta: C.V Andi Offset, 2012).

Kartika Sari, Elsi dan Advendi Simangunsong. Hukum Dalam Ekonomi, (Jakarta: Grasindo, 2007).

Prodjodikoro, Wirjono. Azas-Azas Hukum Perjanjian. (Bandung: Mandar Maju, 2000). 
Analisis Putusan Pembatalan Perjanjian Perdamaian Homologasi Pada Kasus Kepailitan PT Njonja Meneer

(Studi Kasus: Putusan Pengadilan Niaga Semarang Nomor 11/Pdt.Sus-Pailit/2017/Pn Niaga Smg. Jo.

Putusan Mahkamah Agung Nomor 1397 K/Pdt.Sus-Pailit/2017)

Remy Sjahdeini, Sutan. Hukum Kepailitan Memahami Undang-Undang No.37

Tahun 2004 Tentang Kepailitan. (Jakarta: PT Pustaka Utama Grafiti, 2009).

Harahap, M. Yahya. Hukum Acara Perdata. (Jakarta: Sinar Grafika, 2005).

Mahmud Marzuki, Peter. Penelitian Hukum. (Jakarta: Kencana Prenada Media Group, 2005).

Fajar, Mukti dan Yulianto Achmad. Dualisme Penelitian Hukum Normatif dan Empiris. (Yogyakarta: Pustaka Pelajar, 2015).

Soekanto, Soerjono. Pengantar Penelitian Hukum. (Jakarta: UI Press, 1986).

M.S, Salim. Hukum Kontrak : Teori dan Teknik Penyusunan Kontrak. (Jakarta: Sinar Grafika, 2010).

Syahrani, Riduan. Seluk-Beluk dan Asas-Asas Hukum Perdata. (Bandung: Alumni, 2006).

Hartini, Rahayu. Hukum Kepailitan. (Malang: UMM Press, 2007).

\section{Peraturan Perundang-undangan:}

Indonesia, Undang-undang Nomor 37 Tahun 2004 tentang Kepailitan dan Penundaan Kewajiban Pembayaran Utang (Lembaran Negara Republik Indonesia Tahun 2004 Nomor 131, Tambahan Lembaran Negara Republik Indonesia Nomor 4443).

Kitab Undang-Undang Hukum Perdata.

\section{Putusan:}

Putusan Mahkamah Agung Nomor: 1397 K/Pdt.Sus-Pailit/2017.

Putusan Pengadilan Negeri Semarang Nomor: 11/Pdt.Sus-PKPU/2017/PN Niaga Smg jo. Nomor: 01/Pdt.Sus-PKPU/2015/PN Niaga Smg.

Putusan Pengadilan Niaga Semarang Nomor: 01/Pdt.Sus-PKPU/2015/PN Niaga Smg. 